\title{
Manufacturing Small And Medium Size Enterprise's Offshore Outsourcing And Competitive Advantage: An Exploratory Study On Canadian Offshoring Manufacturing SMEs
}

\author{
Muhammad Mohiuddin, Ph.D. Candidate, Laval University, Canada
}

Zhan Su, Ph.D., Laval University, Canada

\begin{abstract}
This paper explores whether and how the offshore outsourcing of the manufacturing SMEs creates competitive advantages for these firms. The offshore outsourcing strategy is widely criticized in the developed countries for allegedly reducing job opportunities, missing scale economy, diminishing innovation potentialities and creating various social problems. The present article with empirical data from thirteen Canadian offshoring manufacturing SMEs attempted to address that the world-wide distributed co-production network could instead increase profit and market share, boost investment in $R \& D$, raise focus on core competency and enhance competitivity of offshoring SMEs. This strategy enables companies to enhance their competitiveness by allowing them to have access to the competitive production factors and new markets for their products. This paper contributes to the existing body of knowledge by showing that not only the large multinationals but also the SMEs can achieve competitive advantages from offshoring part of their activities to foreign firms where those 'tasks' can be performed more competitively.
\end{abstract}

Keywords: Small and Medium Size Enterprises (SME's); Offshore Outsourcing; Competitive Advantage; Case study

\section{INTRODUCTION}

lobalization, emergence of new technologies and rise of smart manufacturing techniques allowed firms to fragmenting their production processes, slicing up the value chain, and distributing them in the Global production network (GPN). In modularization of the manufacturing process, components made in one country are shipped to another country for further transformation and/or assembling in another country. The existing laws, policies and management practices, are particularly often inconsistent with this changing reality (Ferdows, 1997). The 'slicing up' of the aggregate value chain represents a substantial change in the new post-Fordist production paradigm and is largely discussed by researchers specializing in international business studies (Mudambi, 2007; 2008; Globerman, 2011). The fragmented value chain in various industries and service sectors shows that the division of labor can proceed outside the boundaries of the firm. Offshore outsourcing strategy arose from this new production paradigm, became an essential business strategy, gradually increased in terms of scale, scope and pace over the last two decades, (Zee \& Brandes, 2007; Mohiuddin, Z. Su \& A. Su, 2010). What changed in strategic management thinking is that the dominant view of analyzing 'competitive advantage' of firms no longer remained inside the organization (Porter, 1985; Mintzberg, 1983) but extended to the supply network of the firm. Today's competition is among the different supply chains rather than the individual firms (Harland, 1996). 
There are several terms such as outsourcing, offshoring, purchasing, contract manufacturing, international sourcing to name a few, are used to mean "offshore outsourcing" in the literature. In this study, we adopted "offshore outsourcing" as the "management of follow of components and finished products and know-how across the nations in serving local and international markets". According to Huws \& Dahlmann (2004: 3), offshore outsourcing brings two concepts together; geographical and legal. Offshoring is the geographical dimension that refers to the relocation of any part of a firm's value chain beyond national borders. In its legal sense, outsourcing refers to procuring components or services from an external source rather than producing internally. Globalization, financial market and shareholder's pressures and accelerated competition as well as 'increasing consumer demand for value' have pushed firms to look for more efficient and cost effective way of production with limited resources. One of these strategies comprises relocating and outsourcing to low cost suppliers from emerging countries in order to lower overall production costs by reaping advantages from competitive production factors and gaining higher profits. There is evidence that outsourcing contributes positively to market value (Alexander \& Young, 1996) of large firms. However, many companies are unable to achieve the supposed advantages from this strategy. Offshore outsourcing by the manufacturing SMEs is relatively new, and there are a terribly limited number of rigorous studies looking at the outcome of SMEs offshoring (Gorg \&Hanley, 2004; St-Pierre, 2011; Mohiuddin \&Su, 2010) with significant differences of outcome among those researches. The SME size constraints along with relatively weaker managerial and financial capabilities might hold back them to exploit the opportunities fully from the offshore outsourcing. On the top of that, the operational cost-cutting strategy can easily be replicated by competitors and may not provide long term competitive advantage for the offshoring SMEs. A fundamental question, therefore, arises whether offshore outsourcing is a value enhancing strategy or not for the manufacturing SMEs. Kimura (2002) does not find any evidence that sub-contracting leads to higher profits in Japanese manufacturing firms. Gorzig and Stephan (2002) find that outsourcing of materials is positively correlated with profits for a sample of German manufacturing firms. Gorg \&Hanley (2011) show that offshore outsourcing of production allows firms to access cheaper inputs abroad, foster gains from international specialization and lead to the restructuring of production in the industrialized countries toward more 'skill-intensive' or innovative activities. Leahy and Montagna (2008) show that firms outsourcing may lead to higher cost, and lower profits as a result. Jabbour (2008), Tomiura (2004), and Daveri and Lasinio (2007) have studied the impact of offshore outsourcing on firms productivity. They did their studies on French, Japanese and Italian manufacturing firms respectively and found conflicting results. Gorg and Hanley (2004) found from their study on Irish electronics industry that large enterprises (LE) benefit from outsourcing but not the SMEs. Large firms may have better market power, knowledge on competitors and suppliers and less transaction cost than the SMEs. Previous studies show offshore outsourcing strategy is widely used by Multinational corporations (MNC) (Doh, 2005; Kotabe, 1992). Through offshore outsourcing, the SMEs can reduce costs and increase efficiency in their business processes. Offshoring can provide the SMEs with an excellent way to overcome size and capacity related shortcomings, save money and become more profitable. The efficiency enabled by outsourcing also makes these companies more attractive to investors, thus helping them grow even more. The benefits from outsourcing can be enormous, but for many SMEs outsourcing is simply a matter of survival. Gorp, Jagersma, \& Livshits (2007) showed that increasing numbers of small and medium-sized enterprises are engaged in offshore outsourcing. Van Gorp's research shows that offshore outsourcing is likely to increase. St-Pierre (2011) shows that 17\% Quebec manufacturing SMEs are engaged in offshore outsourcing. However, Very little research was conducted on effects of strategies and processes of offshore outsourcing activities of small and medium-sized manufacturing enterprises (SMEs) (Mohiuddin \& Su, 2010). Further from a recent database search in EBScohost and ABI/Proquest with the key word "Offshore outsourcing of SME", we found only 12 and 14 articles respectively where only 3 and 2 articles respectively falls in the SME offshoring topic. This clearly shows the paucity of research on this topic in spite of the fact that offshoring of manufacturing SMEs can be a valuable business strategy which can provide them to compete in the global marketplace. In our knowledge, no rigorous study was done on the Canadian manufacturing offshoring SMEs even though the manufacturing SMEs plays a pivotal role in Canadian economy. This paper argues that the offshoring SMEs can overcome the size-induced resource constraint and develop networked structure and can behave in the marketplace as a single larger firm, thereby achieving market penetration through synchronized competency building (Liesch et al., 2012; Manring \&Moore, 2006). However, the SMEs offshoring motivation, benefits and experiences can differ significantly from those offered to MNCs (Scully \& Fawcett, 1994). SMEs may act in a more entrepreneurial fashion, focus on a niche market and are likely to be more ready to react and adopt innovations that arise from offshoring partnerships (Di Gregorio et al., 2009). This paper thus will explore the research question; whether and how the Canadian offshore outsourced manufacturing SMEs create value and enable them to grow and be more competitive in the market place? This paper sheds light on 
the offshoring manufacturing SMEs if the offshoring strategy enables them to realize the competitive advantages and prosper in the marketplace. We believe manufacturing SMEs enter into offshore outsourcing not only to offshore part of their production activities to the suppliers as a defensive strategy, rather, they try to get access to the resources from the market and improve their overall competitiveness, blurring the organizational boundary.

We investigate our research question through a multiple case study of 13 Canadian manufacturing offshoring SMEs. The choice of case study method was first, due to the paucity of empirical evidence and theoretical reflection on the topic of new business opportunity recognition within ongoing internationalization initiatives such as SME offshoring (Eisenhardt, 1989; Yin, 1994). Second, the unavailability of reliable data sources on manufacturing SMEs engaged in offshore outsourcing or 'Trade in task' i.e. vertical trade. Conventional trade measures of imports and exports have problems measuring the extent of vertical trade, and those measurement problems can confound interpretations of where and how production and value are created (Conference board of Canada, December, 2011). The case study method can help us to study this "contemporary phenomenon in its reallife context, especially when the boundaries between phenomenon and context are not clearly evident" (Yin, 1981, p. 98). There are many reasons that motivated us to choose Canadian offshoring manufacturing SMEs as our study subject. The share of manufacturing in Canadian GDP is comparatively high among the G7 countries and more than 98\% of Canadian manufacturing firms are the SMEs. The per capita export of Canada is next only to Germany and highly dependent (approximately 75\%) on the USA market. Moreover, Canadian manufacturing is being integrated increasingly into the Global Value Chain (GVC). Canadian manufacturers are facing the challenges of combining efficiently \& simultaneously low cost competition, global sourcing, supply chain agility, and increasingly new opportunities from the emerging markets. The rising competition and volatility in the USA market and concurrently increased quality and reliability among the suppliers from advanced emerging countries such as China have created the Low cost country sourcing (LCCS) more appealing (Kusaba et al., 2011) for Canadian manufacturers. The 13 cases we have selected for our study do their offshoring in the emerging countries. Small local market and Export oriented manufacturing in Canada deserve a particular attention for exploring whether offshoring can allow SMEs to remain competitive facing competitors from the emerging countries. We believe an in-depth case study method can fulfill this requirement.

This paper is organized as follows. In the next section, theoretical framework is presented, with a review of the literature on offshore outsourcing in the context of new global division of labor (NGDL) (Su, 2009; Gorg \& Hanley, 2011) and modularization of the production process. The description of the methodology follows with the research design used in this study. The last section deals with the findings and discussion along with a conclusion at the end.

\section{NEW GLOBAL DIVISION OF LABOR (NGDL) AND OFFSHORE OUTSOURCING}

\subsection{Global Value Chain (GVC) and 'Smile Curve'}

Global Value Chains (GVCs) are international supply chains characterized by fragmentation of production activities across sites and borders (Lunati, 2007). In fact, the whole process of production, from acquiring raw materials to producing and delivering a finished product, has increasingly been "sliced", so that each activity that adds value to the production process can be carried out wherever the necessary skills and materials are available at a competitive cost (OECD, 2007; Feenstra, 1998). The GVC, in turn, correlates positively with the offshore outsourcing (Globerman, 2011; Jara, J. \& Escaith, H., 2012). Standardization, mechanization and modularization have permitted co-production of manufacturing goods across the globe depending on the cost-effective availability of various inputs for any typical products. Empirical research (Belussi \& Sedita, 2010 \& Mudambi, 2008) shows that offshoring to emerging countries very often creates low-to-medium-value-added labour intensive activities and more higher-valued and high-value-added jobs are mostly kept in the developed countries. The smile curve (Dedrick, Kraemer \& Tsai, 1999; p.156) shows (Figure 1) this phenomenon clearly. 


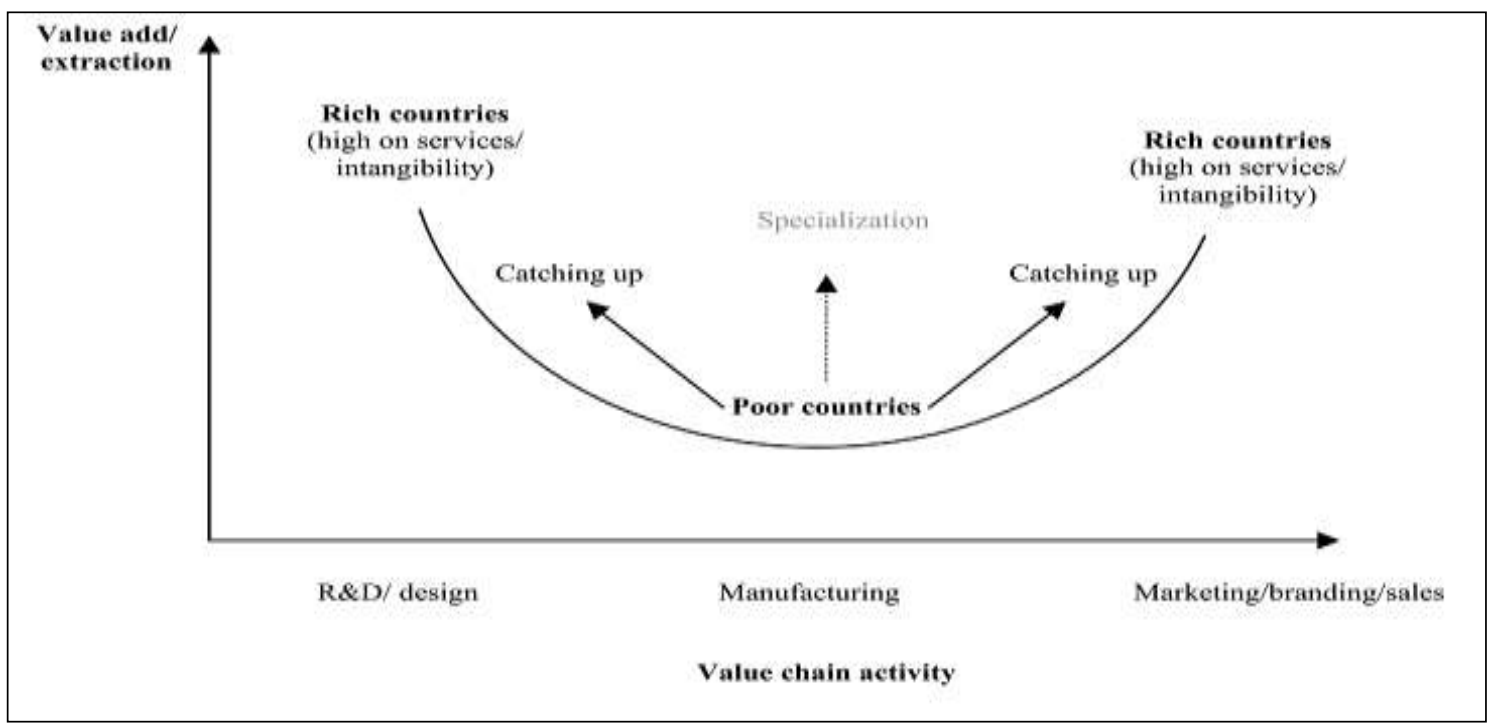

Figure 1: Smile curve and positioning of the emerging countries

Higher value added activities are concentrated at the both end of this curve where the developed countries with their superior capabilities can compete. Activities at both ends of the 'Smile curve' are intensive in their application of knowledge and creativity. Activities at the left end or 'inputs' are supported by R\&D knowledge, while activities at the right or 'output' end are supported by marketing knowledge (Su, 2009; Mudambi, 2007, 2008). On the other hand, emerging countries such as China or India can contribute to the bottom of the curve that is labor intensive and comparatively low-value-added activities. Firms combine the comparative advantages of geographic locations with their own resources and competencies to maximize their competitive advantage (McCann $\&$ Mudambi, 2005). The interplay of comparative and competitive advantage determines both the boundaries of the firm and the optimal location of the value chain components (Mudambi, 2008). Pyndt and Pedersen (2006) have also found a similar pattern in their study on large Danish companies. The distribution of 'tasks' according to the respective capabilities enables firms from the developed and emerging countries to participate into the Global Value Chain (GVC), (Torsilieri \& Lucier, 2000; UNCTAD, 2011; Jara, J. \& Escaith, H., 2012). Trade across national borders is increasingly consisting of intermediate products rather than complete goods or services (Pyndt \& Pedersen, 2006). A key factor in the internationalization of business is the international fragmentation of production (Curran \& Zignago, 2011) which represents 50\% of international trade exchanges (WTO, 2011). Increasing modularization allows firms, specially the SMEs, to amplify its focus on niche activities within the value chain, associated with the highest value-addition, an approach that may be called 'fine slicing' (Mudambi, 2008). It allows the SMEs to outsource other activities associated with lower value-addition more cheaply and efficiently (Ernst \& Lim, 2002) and allows having access to the resources it lacks. This analysis shows the rationale for the SMEs to slice their value chain into separable self-contained components or modules (Kotabe, Parente \& Murray, 2007). This 'task distribution' across the borders can enables developed country firms (DCF) to have a 'cost effective and competitive production web' and simultaneously creates economic opportunities in the emerging countries. Offshore outsourcing allows the SMEs to increase their participation in the global value chains (Gereffi, (2005).

The globalization of 'Tasks' also creates strong interdependence among countries and firms, characterized by increased trade in intermediate goods, services and know-how, as well as by multi-localization of fragmented production web. This paradigm shift in distributed production system has given rise to public debates and policy concerns about the possible impact of this increasingly new global division of labour (NGDL) (Gorg \& Hanley, 2011; Su, 2009). The NGDL enables SMEs to reap benefits from the comparative advantages in terms of low-costhigh-value production factors and business networks (Su, 2009; Arndt \& Kierzkowski, 2001) and increasingly enables them to enter to the new markets in the emerging countries. According to Berger (2006), "in the world of fragmented production system", business goals can be achieved by positioning at any point in the value network where the firm has the best-in-the-class capability. The offshore outsourcing is part of this changing networked production system. Low-value-added activities, or routinized production, are under more pressure to be externalized 
and relocated to low-cost countries (Belussi \& Sedita (2010) than the capital-intensive manufacturing. In general, four motivations such as market-seeking, resource-seeking, efficiency-seeking as well as competition-seeking, drive companies to enter into the offshoring boat (Dunning, 2000; Abidi, Su \& Mohiuddin, 2011).

\subsection{Theoretical framework of Offshore Outsourcing}

Offshore outsourcing is a multi-dimensional and multi-faceted business strategy explained by theoretical perspectives imported from other fields such as economics, strategy, sociology, and system science. The main assumption across economic theories is that agents enter into outsourcing and engage in contracts to minimize total costs and to mitigate risks. In strategic management theories, Agents build or acquire resources to execute strategies that lead to 'winning'. The varieties of theoretical approaches used in offshore outsourcing research mean the preparadigmatic state of this field. Embryonic state of theoretical development on offshore outsourcing research also corroborate in Treffler's (2008) research who asserts that many Canadian firms have yet to recognize the sea change in their sourcing possibilities. Nor do they adequately understand that offshoring will enable them to concentrate on core activities that will improve their efficiency and competitiveness. Offshore outsourcing enhances firm performance because it helps firms operate more efficiently through cost reduction and managerial focus on core competencies (Javalgi et al., 2009, Gulbrandsen, Sandvik, \& Haughland, 2009; McNally \& Griffin, 2004). Through focusing on the core competencies, firms can improve organizational skills, invest more resources to enable them to adapt quickly with the competitive environment, overcome the challenges, and finally prosper in the long run. Grossman and Rossi-Hansberg $(2006 ; 2008)$ discuss the offshoring phenomenon in terms of 'trading tasks' whereby the production process is modeled as a continuum of discrete tasks. Within this framework, offshoring of specific tasks can lead to productivity improvements in the importing sector which, in turn, can lead to an expansion of output in that sector. Even though, a country enjoys comparative advantage in an industry, there can have one or more specific tasks where this country has comparative disadvantage. Offshoring these tasks where other locations enjoy a comparative advantage could increase productivity in the tasks retained by the outsourcing firms. Jones (2006) and Bhagwati, Panagariya and Srinivasan (2004) argue that offshore outsourcing is fundamentally a trade phenomenon, and results in gains from trade. Baldwin (2009) and Baldwin and Robert-Nicoud (2010) argue that a fundamental difference between the trading tasks models of trade and older models of trade is that, since offshoring can affect all sectors, it is unclear which groups in society will gain or lose from increased trade intensity. Scully and Fawcett (1994) found in their study that SMEs experiences few benefits from international sourcing and views international sourcing as less helpful in competing with low-cost manufacturers. On the other hand, Sinha, Akoorie, Ding, Wu (2011) found that manufacturing offshore outsourcing enables SMEs to gain the benefits of flexibility, lower production costs and customized delivery without incurring the costs of administrative fiat--as would be the case if they used foreign direct investment as an entry mode. Manufacturing offshore outsourcing enables the SME to operate within the constraints of its limited physical and managerial resources. Among the multiple theories, two influential theories in the study of offshore outsourcing have been transaction cost economics (TCE) and the resource-based-view (RBV) (Vivek et al., 2008; Jiang et al., 2007). These theories can equally guide research on offshoring of the SMEs as the motivations for offshoring are similar like large enterprises (Gregorio et al., 2009).

In the TCE approach, the properties of the transaction determine what constitute the most efficient governance structure-market, hierarchy or alliance (Williamson, 1975). A TCE approach helps conceptualize firm offshoring in terms of the specificity of assets, uncertainty around strategic options, and the infrequency of such arrangements (Williamson, 1985). When asset specificity and uncertainty are low, and transactions are relatively frequent, transactions will be governed by markets such as offshore outsourcing contracts. Hierarchical governance occurs when uncertainty and high asset specificity lead to transactional difficulties. Medium levels of asset specificity lead to bilateral relations in the form of co-operative alliances between the organizations-inter-mediate governance (McIvor, 2009). 'Transaction cost economics (TCE)' implies that firms should produce goods in-house if the transaction cost of 'market based contract' is higher and arrange to produce through the 'market based contract' if this transaction cost is lower than producing in house (Mohiuddin \& Su, 2010). According to the TCE, in-house operations that are more commoditized than others stand to benefit from the market aspects offshoring arrangements (McNally \& Griffin, 2004). The main objective of offshoring is to reduce cost (Doh, 2005; Farrell, 2005; Bengtsson et al., 2009) especially labor and production and to increase revenues (Sanders et al., 2007). SMEs can utilize offshore manufacturing outsourcing to gain the advantages of foreign location-specific advantages without having to incur the cost of operating and managing full-scale multinational operations. SMEs with their entrepreneurial 
capability and flexibility could avail the advantage of emerging opportunities from offshore outsourcing that MNCs might overlook or lack the administrative flexibility to engage in (Sinha, Akoorie, Ding, \& Wu, 2011). However, offshoring of the SMEs can also come with many risks and hidden cost (Ellram et al., 2008). Firms can overemphasize the cost minimization and neglects the value creation aspects of a transaction (Tsang, 2000). It can drive firms to loss of Interfaces/economies of scope; fall in hollowing-out, victim of opportunistic behavior of the outsourcing supplier's firms. Geographical, economic and cultural distance between the client and supplier firms can contribute to rising transaction and coordination costs, limited learning and innovation (Kotabe, et al. 2009; Moatti, 2008) scope.

The RBV approach, on the other hand, assumes that firms try to maximize long-term profits through exploiting and developing resources for competitive advantage (Javalgi, Dixit, \& Scherer, 2009). Theory of resource-based view (RBV) of the firm has been employed over the last decade to explain the outsourcing strategy. The RBV can assist with analyzing organizational capabilities, which can link outsourcing with performance and the competitive priorities of the organization (McIvor, 2009). The research on offshore outsourcing is tilted towards the Resource Based view (RBV) approach which can be summarized as the following linear functions:

Outsourcing $=f$ (shortcomings in competitive capabilities+ access to new markets)

Shortcomings $=f$ (resource attributes, allocation, resources \& capabilities + Size of the local market $)$

Firms determine their outsourcing strategy based on those shortcomings. This is more relevant with the case of the SMEs. Grant (1991, 1996; Mohiuddin \& Su, 2010) points out that the organization's competence depends on its capability to combine resources and organizational processes to meet the desired objectives. Grant (1991) also states that the conventional approach to the creation of resources has focused on company's lack of resources and capabilities. In other words, in order to exploit certain of its resources, the company may need to acquire external complementary resources that it does not possess. Thus, the firm is not limited to exploiting its own stock of resources and capabilities (Das \& Teng, 2000), but can cover its shortcomings by purchasing or developing strategic alliances through offshoring. Therefore, suppliers can also be considered as the source of resources that consolidate the organization's internal competencies. According to Belussi \& Sedita (2010), initially MNC have engaged in exploitative offshoring to new emerging economies for standardized \& low-value manufacturing activities and gradually they entered to the explorative offshoring through outsourcing of knowledge intensive activities. Within the RBV perspective, the core competency approach provides one of the most powerful frameworks for explaining why firms outsource their resources through market agreements (Gilley \& Rasheed, 2000). This approach suggests that a firm should invest in those activities that constitute its core competences and outsource the rest (Prahalad \& Hamel, 1990; Quinn \& Hilmer, 1994). SMEs offshoring also creates advantages of interrelationships between two or more organizations. Offshoring creates associative advantages for their internal and relational capabilities. This synergetic approach suggests that critical resources can be expanded or built up beyond the confine of the organizational boundary and be integrated into inter-firm routines and processes. The use of offshoring is considered a strategy in which essential process activities could be outsourced in a framework of long-term cooperation where the suppliers are considered to be partners (Pfohl \& Buse, 2000). Strategic relational value is generated by the development of capabilities across organizational boundaries and can be achieved by the creation of complementary resources that jointly generate synergetic rents (Dyer \& Singh, 1998). The development of relational capabilities with customers and suppliers through process integration (Hammer, 2001); relational competitiveness and simplification of activities (Hammer \& Champy, 1994; Davenport, 1996) can all be influential when process activities are offshored. Thus, offshoring expands the capacity of the firms (Callahan, Smith, \& Spencer, 2013) even it does not possess all the resources and competencies and encourage them to build cooperation even in core competence fields. More and more recent research on offshore outsourcing is focusing on knowledge and innovation acquisition (Abidi, Su, \& Mohiuddin, 2011; Al-Azad et. al. 2010) from the offshore partner firms. Thus, the offshore outsourcing is changing the boundary of firms in the current post-industrial era. The offshore outsourcing strategy, hence, allows combining the best practices in the market place and creating a virtuous cycle. Instead of depending either on absolute, comparative, or competitive advantages, firms are combining their respective advantages with complementary advantages of their partner firm's from abroad and creating a higher level of transnational competitive advantages. Joining to this transformation of world trade and modular production web by Canadian manufacturing firms are likely to achieve its goal of creating enhanced competitiveness and job creation. 
Outsourcing standardized activities allow a SME to focus on core activities and/ or expand output or specialize in certain segments of the value chain, or engage in higher profitable business activities that contribute to long term competitiveness (Gilley \& Rasheed, 2000). Outsourcing improves the organization's responsiveness and "leads to the availability of higher quality goods and services by creating competition among suppliers" (Rasheed \& Gilley, 2005, p. 523). Offshore outsourcing helps a firm to improve the quality of its products and services, thus opening new opportunities in the long term (Ellram et al., 2008). Offshoring can also free managers and resources in order to focus on higher value added activities, new product development and innovation. Outsourcing leads firms to be more flexible in terms of production and adjusting with the market demand and other unprecedented changes (Contractor, et al., 2011). Through investing part of the savings from the offshore outsourcing in R\&D, offshoring firms can increase (i) productivity level and (ii) profitability level (Johansson \& Lööf, 2008). Furthermore, outsourcing can accelerate the product/ process design cycle time if the client uses multiple best-in-class suppliers, who work simultaneously on individual components of the system as each supplier can contribute greater depth and sophisticated knowledge in specialized areas and thus offer higher quality inputs than any individual supplier or client (Quinn \& Hilmer, 1994). Bertrand (2011) with data from French offshore outsourcing firms found the positive link between offshore outsourcing and export. Through Offshoring, client firms become more familiar with supplier firm's markets in terms of cultural differences and business practices. The enhanced understanding of supplier's markets help to reduce various transaction cost and can increase their exports to those markets. The multiple sourcing partners in different time zone can allow round-the-clock production advantages. However, these advantages need to be traded-off with the higher transaction and coordination costs with foreign partners. Many empirical studies have provided support for positive impacts of offshore outsourcing on productivity (Bartelsman et al., 2003). Other relevant theories have examined the potential of productivity enhancing effects due to knowledge spillover as well as firms' abilities to focus on core competencies by outsourcing relatively inefficient activities. According to Kotabe et al. (2009), offshore outsourcing helps firms to improve their strategic focus or to reduce less economic assets, strategic flexibility, avoid bureaucratic costs and relational rent. In the SME context, the core competence approach can assist firms to increase efficiency, free up or borrow resources and retain flexibility, gain access to unique resources and capabilities from abroad, expand relations with strategic partners and serve customers more efficiently (Gregorio et al., 2009). While the TCE approach is primarily about cost minimization, the RBV emphasize on value creation by the offshoring SME through tapping into external sources of innovation and dynamic capabilities that diminishing transportation and communication costs have made possible.

Offshore outsourcing is a multi-dimensional phenomenon that cannot be explained either by the TCE or the RBV approach alone but can enhance our understanding while approaching them as complementary (Ellram et al., 2008; Vivek et al., 2008) to each other. TCE is focusing primarily on governance skills, whilst the RBV focuses primarily on production skills. In addition, outsourcing in practice is being influenced by both capability considerations and TCE variables such as asset specificity and a small number of suppliers (McNally \& Griffin, 2004). The lack of research on offshoring of manufacturing SMEs prompted this paper to develop an offshore outsourcing framework of SMEs integrating the logic of TCE and the RBV.

\section{RESEARCH DESIGN}

The lack of offshore outsourcing theory and the use of multiple theories imported from different fields shows that research in this field is scattered in several directions, and the field is still in a pre-paradigm phase. The comparatively newness of offshore outsourcing of the SMEs require an in-depth exploratory approach to get into the heart of the topic in order to understand what exactly happening to the offshore outsourcing SMEs. This fact led us to choose the interpretative approach such as multiple case studies to gain practical insights of offshore outsourcing of the SMEs on operational as well as strategic level and to build theory on strategic outsourcing. Qualitative case studies can generate novel and accurate insights when the extant theory seems inadequate. A multiple case study is attractive because it permits detections of patterns across classes or clusters to understand complex phenomenon and its dynamics and produces compelling evidence in a robust manner (Stake, 1995; Yin, 2004). Such a design also facilitates assessment of how a phenomenon performs in different settings and environment (Stake, 2006). The case approach is viable for such purposes as rich anecdotal description adds depth, comprehensiveness and knowledge to the understanding of a specific phenomenon (Mintzberg, 1979; Shah \& Corley, 2006). According to Yin (1994), the use of case studies is typical in theory development stages, when investigating events or phenomena that have little or no rigorous theoretical background and not a priori theory can be identified to select case studies and the 
constructs to be examined. The case study is an attractive method, especially when the study question asks in the form of "what is going on" (Bouma \& Ling, 2004; p.17). In fact, 'multiple case studies' is an approach that allows the utilization of advantages of deductive approach and those of the inductive approach for knowledge production. It can provide a thorough understanding of the phenomenon of interest in its real context (Mohiuddin, Z.Su \&A.Su, 2010).

Research on benefits from the SME offshoring strategy on the firm's competitive advantages and growth strategy are quite limited or absent. We chose 13 manufacturing SMEs based on three criteria such as; i) offshore outsourcing activities. Those activities that the SMEs send to the supplier firms for transformation and then imported back to integrate with their products in Canada. Or, these firms forward part of their activities, components or design and conception to the supplier firms in order to be integrated with their components for producing final products and import back to Canada or export to a third country as final goods or intermediate goods, ii) Business size. For the purpose of our study, we used the number of employees which appeared straight forward and sufficient. From 10 to 49 employees forms the small and from 50 to 499 forms the medium manufacturing enterprises, iii) Line of Business (manufacturing). Some other criteria for the selection of the firm and interviewees are as follows:

Table 1: Case selection criteria

\begin{tabular}{|c|c|c|}
\hline & Measures & Rationales \\
\hline \multicolumn{3}{|l|}{ Criteria for firms } \\
\hline $\begin{array}{l}\text { Offshoring } \\
\text { experience }\end{array}$ & Three years or more & $\begin{array}{l}\text { To confirm that the firms are familiar with } \\
\text { Offshoring and had time to get adequate } \\
\text { experience. }\end{array}$ \\
\hline Type of Offshoring & $\begin{array}{l}\text { Manufacturing Offshoring from seven different } \\
\text { sectors: High tech (aero-nautics) as well as mid- } \\
\text { and classic manufacturing sectors. }\end{array}$ & To cover a wide range of cases. \\
\hline Firm size & $\begin{array}{l}\text { No less than } 10 \text { employees or more than } 499 \text {. All } \\
\text { of these are medium size firms. }\end{array}$ & $\begin{array}{l}\text { To indicate the activities of of a systematic } \\
\text { management model in Offshoring. A typical firm } \\
\text { whose results can be generalizable. }\end{array}$ \\
\hline \multicolumn{3}{|l|}{$\begin{array}{l}\text { Criteria for } \\
\text { interviews }\end{array}$} \\
\hline $\begin{array}{l}\text { Status of the } \\
\text { interviewees }\end{array}$ & $\begin{array}{l}\text { Mid-to-higher level manager/ decision makers in } \\
\text { Offshoring activities. }\end{array}$ & $\begin{array}{l}\text { To be close or involved with the Offshoring so that } \\
\text { the real pictured can be extracted from them. }\end{array}$ \\
\hline $\begin{array}{l}\text { Experience of the } \\
\text { interviewees }\end{array}$ & $\begin{array}{l}\text { At least three years consecutive experience in } \\
\text { Offshoring activities at the same firm. }\end{array}$ & $\begin{array}{l}\text { To make sure that the interviewees are familiar } \\
\text { with the management process of Offshoring and } \\
\text { the Offshoring issues in their current firms. }\end{array}$ \\
\hline $\begin{array}{l}\text { Knowledge towards } \\
\text { offshoring }\end{array}$ & Expected to have sufficient Offshoring knowledge & $\begin{array}{l}\text { To indicate that the interviewees can understand } \\
\text { the questions be asked and can provide appropriate } \\
\text { answers. }\end{array}$ \\
\hline
\end{tabular}

There is no government or private organization which maintains the database of the offshoring firms. In order to find offshoring manufacturing SMEs respecting our criteria, we contacted the chambers of commerce, manufacturing \& exporting association as well as the Data bank of Québec manufacturers 'Centre de recherché industrielle du Québec (CRIQ)'. From a list of 453 manufacturing SMEs who are also exporters, we have contacted by telephone and spoke with a senior manager (vice-president or manager of international purchasing division) and requested for an interview if the firm fulfills our criteria. Usually, four to ten cases are considered effective for deriving maximum benefit from a multiple-case study research (Eisenhardt, 1989; Stake, 1995). We found 13 firms from 9 different sectors who agreed for the interview for our case studies. In order to keep the confidentiality of their data, we decided to keep only the name of the sector of these firms. Their sectoral classifications are: i) Furniture industry; ii) Automobile parts industry; iii) Garments industry; iv) Electronics \& Electrical industry; v) Industrial equipment; vi) Ceramics and vii) Aeronautics'; viii) Leather industry; ix) Machine \& tools industry. There were three types of firms; i) Capital (high-tech) intensive; ii) Medium capital intensive; iii) Labor intensive. Product complexity is the highest for the capital intensive firms and lowest for labor intensive firms. As the unit of analysis, we have used the firm level effects from SME offshoring.

From this choice of firms, it can be assumed that it represents the leading manufacturing sectors and can triangulate data across the sectors. Another important aspect of this choice is the combination of the low-tech 
industry like garments, furniture, ceramics and electronic and high-tech manufacturing like industrial equipment, aeronautics and automobiles. This will allow us to observe the differences of outcome of SME offshoring according to their technological complexity of their products as well as to explore the avenue of short term versus long term advantages of the SMEs. Further distinction among them was the destination country of their outsourcing. Aeronautics outsourcing was to the firms from Mexico, Brazil and India while other firms collaborated with the Chinese supplier firms. There were also differences in degree of outsourcing. While low-tech and mid-tech firms outsource to China at least $20 \%$ or more of their activities, aeronautics firms outsource around $5 \%$ of their activities. Choice of multiple case study method suits perfectly with these varieties of cases.

Table 2: Characteristics of the sample SMEs

\begin{tabular}{|c|c|c|c|c|c|c|c|c|}
\hline & Industry & $\begin{array}{c}\text { Product } \\
\text { complexity }\end{array}$ & $\begin{array}{c}\text { Foreign } \\
\text { office }\end{array}$ & $\begin{array}{c}\begin{array}{c}\text { Number } \\
\text { of } \\
\text { suppliers }\end{array} \\
\end{array}$ & $\begin{array}{c}\begin{array}{c}\text { Importance } \\
\text { of } \\
\text { Negotiations }\end{array} \\
\end{array}$ & Motivations & $\begin{array}{c}\text { Cul } \\
\text {-ture }\end{array}$ & $\begin{array}{c}\% \\
\text { offshored }\end{array}$ \\
\hline Furniture & Furniture & Low & Yes & Multiple & Low & $\begin{array}{l}\text { Cost cut, scale, } \\
\text { survive }\end{array}$ & Yes & $>20 \%$ \\
\hline Shoe & leather & Medium & Yes & Multiple & Low & $\begin{array}{l}\text { Cost cut, scale, } \\
\text { survive }\end{array}$ & Yes & $>20 \%$ \\
\hline Auto & Auto & Medium & Yes & Multiple & Medium & Cost cut & Yes & $>20 \%$ \\
\hline Garment & Apparel & Low & Yes & Single & Low & $\begin{array}{l}\text { Cost cut, scale, } \\
\text { survive }\end{array}$ & Yes & $>20 \%$ \\
\hline $\begin{array}{l}\text { Electroni } \\
\text { c }\end{array}$ & electronic & Medium & Yes & Multiple & Low & $\begin{array}{l}\text { Cost, scale, } \\
\text { survive }\end{array}$ & Yes & $>20 \%$ \\
\hline Ceramic & ceramic & Medium & Yes & single & Low & Cost & Yes & $>20 \%$ \\
\hline $\begin{array}{l}\text { Electric } \\
\text { (G) }\end{array}$ & electric & Medium & Yes & Multiple & Medium & $\begin{array}{l}\text { Cost, scale, new } \\
\text { markets }\end{array}$ & Yes & $>20 \%$ \\
\hline $\begin{array}{l}\text { G-high } \\
\text { tech }\end{array}$ & $\begin{array}{l}\text { High-tech } \\
\text { Textile }\end{array}$ & High & Yes & Multiple & Low & $\begin{array}{l}\text { Cost, scale, new } \\
\text { market }\end{array}$ & Yes & $>20 \%$ \\
\hline Tools & $\begin{array}{l}\text { Equipmen } \\
\mathrm{t}\end{array}$ & High & Yes & Multiple & Medium & $\begin{array}{l}\text { Cost, scale, New } \\
\text { product \& } \\
\text { markets }\end{array}$ & Yes & $>20 \%$ \\
\hline I.E & $\begin{array}{l}\text { Industrial } \\
\text { equipment }\end{array}$ & High & Yes & Multiple & Medium & $\begin{array}{l}\text { Cost, scale, } \\
\text { market }\end{array}$ & Yes & $>20 \%$ \\
\hline Aero 01 & Aerospace & High & Non & Single & Non & $\begin{array}{l}\text { Access to know- } \\
\text { how, talent }\end{array}$ & No & $5 \%$ \\
\hline Aero 02 & Aerospace & High & Non & Single & Non & $\begin{array}{l}\text { Access to know- } \\
\text { how, talent }\end{array}$ & No & $5 \%$ \\
\hline Aero 03 & Aerospace & High & Non & Single & Non & $\begin{array}{l}\text { Access to know- } \\
\text { how, talent }\end{array}$ & No & $5 \%$ \\
\hline
\end{tabular}

In order to investigate on the effects of offshoring activities of the manufacturing SMEs on their competitive advantages as well as if this can be a growth strategy in addition to widely believed efficiency strategy, we took seven constructs drawn from various earlier works of academic scientific articles (Kakumanu and Portanova, 2006; Gokhale, 2007) as well as from professional research of leading consulting firms like Mc-Kensy, Accenture and Industry Canada. The Seven constructs are: i) Changes in annual turnover of the company following the offshore outsourcing; ii) Increase of profits; iii) Job creation ; iv) Higher level of investment in R\&D activities; v) Enhanced focus on "core competences"; vi) Improvements in overall competitiveness of the firm; vii) Level of customer satisfaction.

The construct 'competitiveness' refers to the ability of firms to compete for markets, resources and revenues, as measured by indicators such as relative market share, growth, profitability or innovation (Kotabe et al., 2012; Roberts, 2004; Greenwald \&Kahn, 2005). In the long run, competitiveness derives from an ability to build, at lower cost and more speedily than competitors. The real sources of advantages are to be found in management's ability to consolidate corporate-wide technologies and production skills into competencies that empower individual business to adapt quickly to changing opportunities (Prahalad \& Hamel, 1990). The R\&D, according to the Organization for Economic Co-operation and Development (OECD, 2008), refers to "creative work undertaken on a systematic basis in order to increase the stock of knowledge, including knowledge of man, culture and society, and 
the use of this stock of knowledge to devise new applications". Higher investment in R\&D has also included the higher spending in professional development training of the employees thus improving the productivity and capability of the personnel so that the enhanced human capital can contribute to innovation and create valuable, rare, inimitable and non-substitutable resources which can contribute to the long term growth. Core competencies are the company's collective knowledge about how to coordinate diverse production skills and technologies. Focusing on core competencies creates unique, integrated systems that reinforce fit among the firm's diverse production and technology skills- a systemic advantage that competitors cannot copy (Jacoby \& Figueiredo, 2008; Prahalad \& Hamel, 1990).

We have used in-depth semi-structured interviews in order to collect data from the mid-to-higher level managers of the selected firms. We designed an interview protocol with the set of semi-structured questions related to our research question before the interview, to guide our data-collection process. Interview method is an effective way of soliciting and documenting, in their own words, an individual's or group's perspectives, feelings, opinions, values, attitudes, and beliefs about their personal experiences and social world, in addition to factual information (Saldana, 2011; p. 32). The choice of mid-to-higher level managers, we call them 'strategic managers', was based on the kind of strategic questions we are investigating and only these strategic managers can have the answer to policy oriented questions. We had established an interview protocol containing broad structured questions/interview guide (Annex: 01) on SME's offshoring before starting the interview. The question was drawn from the literature review in this field. Based on the interviews, more in-depth questions were developed in order to gather more insightful data that reflect interviewee's own perspectives and experiences. We tried to gather the basic information on offshoring of the sample firms as well as specific information such as effects of offshoring on several performance indicators (McIvor et al., 2009) and overall competitivity in order to observe if the offshoring is beneficial to these firms. All the interviews were recorded and analysed using the "content analysis method" which is "a research technique for making replicable and valid inferences from texts (or other meaningful matter) to the contexts of their use" (Krippendorff, 2003, p.18). We have also studied the annual reports, news and published articles in the daily \& weekly magazines(i.e. les Affaires) on our ' sample firms' and other documents regarding these firms. Some of these documents are available publicly, and others privately procured through signing of confidential letters. We used an inductive approach for 'content analysis method' by Nvivo to study these documents. Efforts were deployed to triangulate or corroborate out hunches about specific constructs and patterns. We have paid particular attention to challenge evidence in order to investigate the several possible effects of offshore outsourcing strategy. Our case study approach is mix of exploratory and explanatory. Explanatory approach assist to observe the influences and effects instead of the positivist constructs of pure 'cause and effects' (Saldana, 2011; p.70) of manufacturing SMEs offshoring on their long term competitive advantage. Exploratory approach explores the possibility of the growth strategy in addition to the efficiency strategy of the SME offshoring. These objectives fit also with our theoretical framework as the TCE approach predicts how the offshoring is organized or choice between 'make or buy' paradigm and the RBV approach predict the strategic orientation of the SME offshoring.

We used several means of interviews; face to face, telephone interview as well as through online questionnaires with at least one senior manager or strategic manager in charge of offshoring activities in each of the 13 companies. The interview questions were around the constructs we took into consideration for this paper. Our interviews were for a period ranging from 70 minutes to 90 minutes and took place from November 2009 to December 2012. This method was highly effective, and executives spoke freely supported by data and their experiences in quest of competitive advantage through outsourcing. We had interactive discussion during the interview and very often, crossed the boundary of our discussion and interview guide. We put emphasis on listening other information that the respective executives thought essential for outsourcing. Knowing "qualitative research does not always lead to the clear conclusion" (Bouma \& Ling, 2004; p.18), we were careful to keep the sequence of events and created a database for each firms and notes on description and interpretation of the data collected. We have recorded the conversation and kept the transcript right after each interview. An analysis of 13 cases, instead of just one, has enabled us to make a better data summarisation. We have then coded the interview notes and transcripts. We have used an iterative process of comparing, coding and analyzing the data that have enhanced the rigor of data analysis. The criteria of validity and reliability of the findings were ensured in every steps of research such as constructs building, interviews, database creation, and data analysis, triangulation of data, data patterns and replication logics in similar firms. Finally, transcripts of the interviews were validated by the interviewees. We employed various tactics in order to minimize observer bias and data-access limitations (cf. McKinnon, 1988). For 
instance, it was agreed not to reveal the companies real names or to give rigorous descriptions of their fields of operation.

\section{DISCUSSION AND ANALYSIS OF RESULTS}

The main objective of this research was to get an in-depth understanding on influences and effects of SMEs offshoring to these firms in terms of competitive advantages and whether the offshoring is a growth strategy for offshoring manufacturing SMEs, in addition to the efficiency related advantages. Characteristics of our offshoring sample firms such as Industry, product complexity (low-tech, medium-tech and high-tech), availability of foreign office, number of suppliers, Importance of negotiations, motivations, culture, and percentage offshored are given in Table 2. Effects of offshore outsourcing on firms are given in Table 3.

Within-case analysis reveals that we have three categories of offshoring SMEs such as Low-tech, Mediumtech and high-tech firms. The prime motivations of offshoring for low-tech and medium-tech firms are cost cutting, economies of scale and surviving in the market place. On the other hand, prime motivation for the high-tech firms is to access to know-how, new product development and also for cost advantages (Tools and I.E firm, Table 2). The cost advantage comes not only from low-cost labour but also from the strategic, geographical and institutional comparative advantages that suppliers enjoy. 'VP (procurement) garment' asserts, "Factors such as 'cost reduction, maintaining global competitiveness, customer demand for value, access to market and reorganizing business process' and host government pro-active policies influence many western firms to relocate to emerging countries". The VP of the medium-tech firm 'Auto' who source OEM (original equipment manufacturing) from China said, "China has been a low-price market for foreign companies for a long time, and still is, due to a large amount of factories". That means the competition among the supplier firms keeps the price down to a considerable level. Combining the results from the Table 2 with the finding from Table 3, it shows that low and medium-tech firms could enhance their overall competitiveness, customer satisfaction, investment in R\&D and focus on core competencies.

On the other hand, for the high-tech firms, their prime motivation of Offshoring activities was to get access to the production expertise of specific inputs such as cost effective talents pools (especially for aeronautics firms) as well as new product development and access to new markets (the Tools and I.E firms, Table 2). As the VP sourcing of the 'Electric (G)' said, the offshoring "accelerate our design cycle and at no cost", she said, "You have to invest in equipment and the manufacturing process, but you need to go beyond that" adding "we have components from China that help us to reduce costs here, and 50\% of our design work comes from India".

Despite the different motivations of offshoring depending on the level of product complexity, all the SMEs could focus on their core competencies and improve their overall competitiveness. The sustainable competitiveness depends largely on innovation in areas that fuel growth. Such innovation requires a relentless focus on the organization's core competencies (Koulopoulos, 2006). The 13 companies that we have studied led us to identify fairly positive results of their outsourcing activities (see Table 3). Offshore outsourcing has contributed significantly to overall competitiveness for 10 out of 13 firms. The 'customer satisfaction' has improved significantly for nine out of thirteen firms. Comparatively lower competitiveness advantage for high-tech firms can be explained by the lower rate of their Offshoring. However, all of these firms could improve their competitiveness in various degrees. Customer satisfaction was lowered for one of the 13 firms (Ceramics) due to the poor image of their products 'made in China'. Despite the improvement of the quality of production in China during the last decades, 'Made in China' products still suffers from being synonymous with low quality. However, this is not the case for most of the studied firms. The VP sourcing of the 'Shoe' said in this regards "Chinese companies, in varying degrees, are thoroughly talking about quality; they are discussing quality-tools and certifications. In five years or so one will look back and see a dramatic difference in the quality of products produced in China".

We could not get a detailed breakdown of financial impacts (profit) from outsourcing of these companies. Overall, they all experienced increases of their revenues substantially. Five out of nine low and medium-tech firms could increase their investments significantly in their R\&D activities and development of core competences. The three high-tech aeronautics firms could not, however, do the same. The rate of outsourcing for aeronautics firms was relatively low (5\%) and dispersed geographically. There were no clear link between the offshoring and improvement 
of customer satisfaction. The same was concerning profit and investment in R\&D. Exception to this was the case of two high tech firms 'Tools' and 'Electric $(\mathrm{G})$ '; they have increased their focus on the core competencies, investment in R\&D and improvement in sales and profits. The difference is that these two firms outsourced more than $20 \%$ of their production activities. VP sourcing of the 'Tools firm' said "We have a general rule, that is, we offshore an item, at least for the first time, when we can see a cost advantage of at least $15 \%$ to $25 \%$ ". He adds "We do offshoring, sometimes, in order to have access to the technology what we do not have, and to focus on core activities as we have to be competitive". The strategic positioning adopted by these companies is particularly relevant. By outsourcing to China, Furniture and Automobile companies seek to improve their global competitiveness especially in terms of price while for Garments and Electronics companies, outsourcing to China allowed them to specialize only in a few key processes in the production of their products. According to the executive of the Garments company, "we must put away the activities in which we are no longer competitive against the Asian countries and create here in Canada more activities of higher value added". Another executive from the Electronic Company shared that view: "trying to do everything here is not beneficial at all". The willingness to engage in a process of "New global division of labour (NGDL)" and the ability to keep and develop locally "more strategic, sophisticated and higher value added activities which require a higher level of expertise and technology" are the two determinants in the success of these companies.

Offshoring firms could not create more jobs in Canada except the two (Automobile and Aeronautics 03 firms). The two firms which have created jobs are themselves doing outsourcing work from American as well Canadian MNCs. Offshoring strategy allowed them to take advantage of 'economies of scale' and helped to create better quality jobs in Canada. It should be noted that offshoring has had a somewhat negative impact on the number of production related jobs at Furniture, Garments and Electronics companies in Canada. These firms have created some higher-valued managerial jobs in logistics, distribution and marketing in Canada replacing relatively low-paid but a higher number of manufacturing production jobs thus contributed to job losses in absolute term. While the "Automobile company and Aeronautics 03 " have succeeded in creating more jobs in Canada, the "Garments" and "Electronics" company cut jobs, because of re-engineering of their business processes and 'Furniture company' remains somewhat stable in terms of the number of jobs in pre- and post-outsourcing era. Among the high-tech firms, three out of six firms have created few jobs in Canada. Reducing job opportunities following the offshoring decision is a relatively hotly debated issue in public opinions. However, recent empirical research rarely could establish a direct link between these two issues. Development of the smart manufacturing and structural changes is at least partly reasons behind the diminishing the level of manufacturing jobs. The historic link between manufacturing and the employment opportunity is shrinking.

All these Offshoring firms improved their focus on their core competency. The overall competitiveness of ten out of 13 firms have enhanced significantly thanks to offshore outsourcing.

Table 3: Effects of Offshore outsourcing on Firms

\begin{tabular}{|l|c|c|c|c|c|c|c|}
\hline & $\begin{array}{c}\text { Competitive } \\
\text { ness }\end{array}$ & $\begin{array}{c}\text { Annual } \\
\text { Turnover }\end{array}$ & $\begin{array}{c}\text { Profit } \\
\text { Increase }\end{array}$ & $\begin{array}{c}\text { Investment } \\
\text { in R\&D }\end{array}$ & Focus in CC & $\begin{array}{c}\text { Customer } \\
\text { satisfaction }\end{array}$ & $\begin{array}{c}\text { Job } \\
\text { creation }\end{array}$ \\
\hline Furniture & AAA & AAA & AA & AA & AA & AAA & B \\
\hline Auto & AAA & AA & NA & AAA & AA & AAA & BB \\
\hline Garment & AAA & AA & BB & AAA & AAA & AAA & C \\
\hline Shoe & AAA & AAA & AAA & AAA & AAA & AAA & BB \\
\hline Electronic & AAA & AA & NA & AA & AAA & AAA & C \\
\hline Electric (G) & AAA & AA & AA & AAA & AAA & AAA & BB \\
\hline Ceramic & AAA & AA & AA & NA & AAA & B & C \\
\hline Tools & AAA & AAA & AAA & AAA & AAA & AAA & BB \\
\hline G-high tech & AAA & AA & AAA & NA & AAA & BB & AA \\
\hline I.E & AA & AA & AA & NA & AAA & AA & NA \\
\hline Aero 01 & AAA & AA & AA & B & AAA & AA & B \\
\hline Aero 02 & AA & AA & AA & B & AAA & BB & B \\
\hline Aero 03 & AA & AA & C & B & AAA & BB & AA \\
\hline
\end{tabular}

I.E=Industrial equipment, $\mathrm{CC}=$ Core competency. Note: 1.) Not at all important= C, 2.) Not important=B; 3.) Relatively important=BB; 4.) Important=AA; 5.) Very important=AAA, 6) NA: Not Available. 
Cross-case analysis of the sample firms reveals particularly interesting understanding on the SMEs offshoring. While low and medium-tech firms do offshoring for lower cost advantages and surviving in the competitive market, high-tech firms look for access to the missing technology i.e resources and access to new markets and product development with the offshoring collaboration from foreign firms. The experience of sample firms in this study shows that Offshoring strategy was a success story for most of these firms in various degrees regardless of their sectoral differences. Among the seven constructs which we took into consideration for this study, these firms could improve significantly their overall competitiveness, annual turnover and focus on core competencies. These firms also have improved their conditions in other indicators with various degrees of success. These results from offshoring strategy let us conclude that these firms have succeeded in their quest for higher competitiveness. Cost advantage for the low and medium-tech SMEs from offshoring corresponds to the theoretical underpinnings of the "Transaction cost economics (TCE)". The enhancement of the capability from having access to resources (regardless of cost consideration) from partner firms for the high-tech SMEs corresponds to the RBV perspectives. Focusing on and developing certain capabilities is central to the RBV and this paper shows that through investing in $R \& D$ and focusing on core competencies, manufacturing SMEs can enhance their dynamic capabilities enabling them to gain sustainable competitive advantage (SCA) and ensure long term growth without investing their own scarce resources. While TCE and RBV differ in their offshoring decision making process, they complement in focusing on core competencies and $\mathrm{R} \& \mathrm{D}$ regardless of the product complexities of the SMEs.

While low-tech firms mainly entered to this fragmented production system in order to gain from cost advantages and thus took the exploitative offshoring strategy, high-tech manufacturing firms adopted explorative offshoring strategy in order to gain access to and fulfill the shortages of resources and talents from the advanced emerging countries. This is increasingly a noteworthy trend in offshoring. Our case study shows this kind of offshoring improves the competitiveness of outsourcing SMEs and also creates new employment in the home country. However, this kind of offshoring requires organisational capabilities for developing sourcing relationships without losing competencies and resources that enable offshoring firm to compete in the future (Slepniov and Waehrens, 2008). Our discussion with the strategic managers revealed that offshoring successes depend significantly on the rigorous and vigilant management policies specially establishing a mutual trust and long term relationship (Lin, Piercy \& Campbell, 2012) with the outsourcing supplier firms in the emerging markets like China. From the discussion with the managers, we have learnt that offshore outsourcing is an effective strategy for enhancing competitiveness of offshoring firms. However, offshoring client firms need to decide meticulously what and how to outsource in order to be successful in reaping the envisioned benefits. Dekkers (2011) said that firms need to take into consideration of 'core competency' while deciding on outsourcing. Most of the scholars hold opinions that the firm's core activities are not eligible to be outsourced. (Quinn \& Hilmer, 1994; Arnold, 2000; Rashid and Al-Azad; 2013). Hence, the decision makers need to keep core activities inside the firm and outsource the "disposable and core-distinct activities" (Arnold, 2000) to the external providers. Moreover, each firm is different from others and thus managers need to be extremely careful to decide what and how to outsource and to adopt strategies aligned with the respective firm. One need to be very careful during the outsourcing process to take into consideration of those reasons that lead to outsourcing. Several executives of 13 companies asserted "we must know how to use the comparative advantages of other countries for our interests (Furniture firm)"; "an effective and responsible offshore outsourcing is one of the major ways to prevent some manufacturing companies from bankruptcy, and even to avoid the closure of some manufacturing firms in Canada ('shoe' firm)" and "We must take advantage of offshore outsourcing to develop further higher-value-added activities such as research and development in Canada('Tools' firm)".

Though outsourcing may reduce production costs and increase client firm's competitiveness in the shortterm, it can also lead to grave negative side effects such as competitive dilemma and loss of initiatives in client firms (Dolgui, 2010). Managers need to adopt adequate relevant strategies in order to cope with these challenges for longterm viability of their firms. As the general manager of the 'electronic firm' said "Most companies that do offshoring for the first time have a challenging experience". The business environment in the emerging countries is far from perfect for western companies. The cultural differences, the issue of product quality, the lack of certain resources, the problem of protecting intellectual property rights, etc. are some of the difficulties that these 13 companies have encountered in their offshoring ventures. 


\section{CONCLUSION}

The main objective of this paper was to explore whether and how offshore outsourcing enable offshoring manufacturing SMEs competitive in the marketplace. The paper contributes to enhance our understanding of the SMEs offshoring and highlights managerial strategy on how competitive advantages are created from the manufacturing SME offshoring. The findings show that offshore outsourcing brings to formidable benefits and enables SMEs to be more competitive in the market place. Offshoring strategy is driven by the opportunity of reducing operating costs, accessing to an abundant and qualified pool of manpower, improving the global competitiveness of the firm and most importantly, specializing themselves in more strategic and core activities. Based on the experiences of SMEs observed, offshoring those manufacturing activities where Canada does not have comparative advantages is one of the few ways to preserve the competitivity of these firms in international markets and particularly in the American market. As Canadian economy is highly dependent on export to the USA market where Canadian products face steep competition from emerging countries firms, offshore outsourcing creates ' $a$ level playing field' for the Canadian manufacturing firms. Many low-tech manufacturing firms that are no longer competitive in Canada, offshoring their production activities to the low cost countries and investing at the both end of the 'smiling curve' can keep these firms competitive and save at least some jobs in Canada. Mid-tech and hightech manufacturers can have access to competitive production factors and the low-cost-high-value innovation from the suppliers. The comparatively higher rate of per capita export of Canada is partly dependent on imported intermediary components coming from the offshore outsourcing. It is particularly crucial to understand that Canada's low-tech manufacturing firms can still be competitive in terms of revenue and profits earnings and can survive in the current competitive market through the offshoring strategy to the low cost countries (LCC).

This paper makes two principal contributions. First, it shows how manufacturing SMEs creates competitive advantage by adopting offshoring and developing core competencies that lead to the long term growth. Second, the integrative approach of the TCE and RBV allowed us to study SMEs offshoring in a new context, where SMEs focus on leveraging their limited internal resources to draw in collaboration and partnership with external resources not available internally. These finding echo that offshoring is not only about cost cutting but also about accessing to expertise and a growing number of highly skilled and qualified workers (Manning et al., 2008; Lewin et al., 2009). This paper also implicitly establishes positive relation between scale of offshoring and better performance. For SMEs managers, this paper offers a tool for using offshoring as a means to compete effectively with large firms.

Despite the beneficial effects of offshore outsourcing that can be observed from the case study, we are also aware that the results of this study may not allow a generalization as our study is based on different types of cases. Locations of offshoring, type of activities and degree of outsourcing have varied from one firm to another. In general, within the interpretivist tradition, generalization is usually not considered to be the primary goal and, instead, particularization is emphasized (Lincoln and Guba, 1985; Stake, 1995). Some methodologists argue that we cannot claim generalization - that Qualitative inquiry is too local and too case specific for a researcher to assert any transferability (Saldana, 2011; p.112). However, a growing number of scholars consider the generalization as necessary, desirable and inevitable in interpretive research (e.g., Williams, 2001; Golden-Biddle and Locke, 1993; Mason, 2002). In fact, Qualitative studies rely on analytical generalizations while quantitative studies rely on statistical generalizations (Mitchell, 1983). Comparisons across multiple cases cannot rely on a 'statistical' logic and hence the set of cases should not be confused with a sample (Dubois \& Araujo, 2007). However, the subjective evaluation for the objective of offshoring was another weakness of this study. Future research needs to take into consideration of perspectives of the supplier firms as well as the characteristics of the sourcing countries. Most importantly, the future research needs to address "How does offshore outsourcing of SMEs look beyond immediate economic challenges to develop long term strategic goals to compete and win in the global marketplace?" How offshoring SMEs can have access to expertise knowledge, accelerate their product and market development, improve organizational flexibility, faster innovation process and creating dynamic capabilities for long term competitive advantages? 


\section{AUTHOR INFORMATION}

Muhammad Mohiuddin, MBA, DESA, is a $\mathrm{PhD}$ candidate in International Management at the Faculty of Administrative Sciences, Laval University, Canada. His research interests are focused on the emerging markets and sustainable offshore outsourcing. He has presented his research works in major international conferences in Management and won 'best paper award' at the ASAC, 2012 conference. He has also published several articles in peer-reviewed journals. His academic and research excellences enabled him to get award from the CIRRELT, FQRSC, SSHRC, ISESCO and Dean's Award. He teaches courses on 'International Management' and 'Doing Business in Asian Markets' at Laval University. Muhammad Mohiuddin, MBA, DESA, PHD (ABD), PhD Candidate in International Management, Faculty of Administrative Sciences, Laval University, Quebec, Canada. G1V0A7. E-mail: muhammad.mohiuddin.1@ulaval.ca (Corresponding author)

Zhan Su is a Professor of Business Strategy and International Management at Laval University, Canada. He received his Doctorate in Business Administration at the University Grenoble II, France, in 1990. Professor Su has carried out research projects on the strategic management of international joint ventures, the internationalization process of firms, country-risk evaluation, cross-cultural management, comparative management, virtual organization design, and the business world in Asian and other transitional countries. Professor Su has published in numerous journals and books. He has already presented papers in more than eighty national and international conferences. He received several prestigious awards for his research and teaching. He currently holds the Stephen A. Jarislowsky Chair on International Business. Dr. Zhan Su, Professor of International Business and Strategic Management, Director, Stephen A. Jarislowsky Chair on International Business, Faculty of Administrative sciences, Laval University, Quebec, Canada. E-mail: Zhan.Su@fsa.ulaval.ca

\section{REFERENCES}

1. Abidi, O., Su, Z. \& Mohiuddin, M. (2011).Strategic and Organizational Evolutions of High-Tech SME on Global Market. Chinese Business Review. 10(5): 327-339. USA.

2. Al-Azad, M.S., Mohiuddin, M., Rashid, M.M.(2010). Knowledge Transfer in Offshore Outsourcing and International Joint Ventures (IJVs): A Critical Literature Review from Cross-Cultural Context. Global Journal of Strategies and Governance. 1(1): 41-67

3. $\quad$ Alexander, M. \& Young. (1996). Strategic Outsourcing, Long Range Planning, 29(1): 116-119.

4. Arndt, S., \& Kierzkowski, H. (2001). Fragmentation. New production patterns in the world economy. Oxford: Oxford University Press.

5. Arnold, U. (2000). New Dimensions of Outsourcing: A Combination of Transaction Cost Economics and the Core Competencies Concept, European Journal of Purchasing \& Supply Management, 6 (2000): 23-29

6. Baldwin, R.E. \& Robert-Nicoud, F. (2010). Trade-in-goods and Trade-in-tasks: An Integrating Framework. Centre for Economic Policy Research (Great Britain), Volume 15882 of NBER working paper series.

7. Baldwin, R. (2009). Integration of the North American Economy and New Paradigm Globalization. Ottawa: Government of Canada, Policy Research Initiative, Working Paper Series 049.

8. Bartelsman, E., Haltiwanger, J. \& Scarpetta, S. (2003). Microeconomic Evidence of Creative Destruction in Industrial and Developing Countries, Free University Amsterdam and Tinbergen Institute; University of Maryland, U.S. Census Bureau, NBER; and The World Bank.

9. Belussi, F. \& Sedita, S.R. (2010). Managing the fragmented value chain of global business: exploitative and explorative offshoring toward emerging market economies., Devinney Timothy, Pedersen Torben, Tihanyi Laszlo, in (ed.) The Past, Present and Future of International Business \& Management (Advances in International Management, Volume 23), Emerald Group Publishing Limited, pp. 399 - 429

10. Berger, S. (2006). Made in Monde. Paris: Seuil.

11. Bertrand, O. (2011). What goes around comes around: Effects of offshore outsourcing on the export performance of firms, Journal of International Business Studies. 42(2):334-344

12. Bhagwati, J., Panagariya, A. \& Srinivasan, T.N. (2004). The muddles over outsourcing. Journal of Economic Perspectives, 18 (4): 93- 114.

13. Bhanich Supapol, A. (1995). Linkage effects, technology transfer, and the development of small and medium enterprises in the electrical and electronics industries in Thailand, In Bhanich Supapol, A., Transnational Corporations and Backward Linkages in Asian Electronics Industries (United Nations). 
14. Bouma, D. \& Ling, R. (2004). The research process, Oxford University Press, South Melbourne.

15. Callahan, C.M., Smith, R.E., \& Spencer, A.W., (2013), The Long-Term Performance Consequences of Strategic Partnerships In High Tech Industries, Journal of Applied Business Research, 29 (1):217-134.

16. Conference board of Canada, December. (2011). Adding Value to Trade Measures: An Introduction to value-added trade. CBC Briefing.

17. Contractor, F.J., Kumar, V., Kundu, S., \& Pedersen, T. (2011). Global Outsourcing and offshoring: in search of the optimal configuration for a company, In (ed.), Contractor, F.J., Kumar, V., Kundu, S., \& Pedersen, T., "Global Outsourcing and Offshoring: An integrated Approach to Theory and Corporate Strategy", Cambridge University Press, UK.

18. Curran, L. \& Zignago, S. (2011). Intermediate products and the regionalization of trade, The Multinational Business Review, 19(1): 6-25.

19. Das, T. \& Ten, B. (2000). A Resource-Based Theory of Strategic Alliances, Journal of Management, 26 (1): 31-61.

20. Davenport, T. (1996). The Future of knowledge management”, CIO, 1 January, 2012, available at: http://www.cio.com/archive/010196 davenport content.html

21. Daveri, F.\& Lasinio C.J. (2007). Offshoring and Productivity growth of in the Italian manufacturing industries, WP 08/2007, Universita degli Studi di Parma, Italy.

22. Dedrick, J., Kraemer, KL. Tsai, T. (1999). Acer: An I.T. Company Learning to Use Information Technology to Compete', I.T. in Business, Center for Research on Information Technology and Organizations, University of California, Irvine. USA

23. Dekkers, R. (2011). Impact of strategic decision making for outsourcing on managing manufacturing, International Journal of Operations \& Production Management, 31(9):935 - 965

24. Di Gregorio, D., Musteen, M. \& Thomas, D.E. (2009). Offshore outsourcing as a source of international competitiveness. Journal of International Business Studies, 40: 969-988.

25. Doh, J.P. (2005). Offshore outsourcing: implications for international business and strategic management theory and practice, Journal of Management Studies, 42(3): 695-704.

26. Dolgui, A. (2010). Outsourcing, In Proth, Jean-Marie 'Supply Chain Engineering, Springer, p. 77-88.

27. Dunning, J.H. (2000). The eclectic paradigm as an envelope for economic and business theories of MNE activity, International Business Review, 9 (2): 163-190.

28. Dyer, JH. \& Singh, H. (1998). The relational view: Cooperative strategy and Sources of International Competitive Advantage, Academy of Management Review, 23(4): 660-679.

29. Eisenhardt, K.M. (1989). Building theories from case study research. Academy of Management Review, 14(4):532- 550.

30. Ferdows, K. (1997). Made in the World: The Global Spread of Production, Production and Operations Management, 6(2): 102-109.

31. Gilley, M. \& Rasheed, A. (2000). Making More by Doing Less: An Analysis of Outsourcing and its Effects on Firm Performance, Journal of Management, 26(4): 763-790.

32. Globerman, S. (2011).Global Value Chain: Economics and Policy Issues, http://www.international.gc.ca/economisteconomiste/assets/pdfs/research/TPR 2011_GVC/03 Globerman e FINAL.pdf

33. Gokhale, A. (2007). Offshore Outsourcing: A Delphi Study" Journal of Information Technology Case and Application Research, 9(3): 6-18.

34. Gorg, H. \& Hanley, A. (2004). Does Outsourcing increases Profitability? The Economic and Social Review, 35(3):267-288.

35. Gorg, H. \& Hanley, A. (2011). Services outsourcing and Innovation: An empirical investigation, Economic Inquiry, 49(2):321-333.

36. Gorp, D.M. van, Jagersma, P.K., \& Livshits, A. (2007). Offshore behavior of service firms: Policy implications for firms and nations. Journal of IT Case and Application Research, 9(1):7-19.

37. Grant, R. M. (1991). The resource-based theory of competitive advantage: Implications for strategy formulation. California Management Review, 33(3):114-135.

38. Grant, R. M. (1996). Prospering in dynamically-competitive environments: Organizational capability as knowledge integration. Organization Science, 7(4):375-387.

39. Greenwald, B. \& J. Kahn. (2005). Competition Demystified: A Radically Simplified Approach to Business Strategy (New York). 
40. Gereffi, G. (2005). The New Offshoring of Jobs and Global Development: An Overview of the Contemporary Global Labor Market, International Labor Organization (ILO), 7th Nobel Peace Prize Social Policy Lectures, Kingston, Jamaica, December 5, 6 \& 7, 2005.

41. Grossman, G. \& Rossi-Hansberg, E. (2006). The Rise of Offshoring: It's Not Wine for Cloth Anymore, Jackson Hole Conference Volume, Federal Reserve Bank of Kansas City.

42. Grossman, G. \& Rossi-Hansberg, E. (2008).Trading Tasks: A Simple Theory of Offshoring. American Economic Review, 98(5):1978-97.

43. Gulbrandsen, B., Sandvik, K., \& Haugland, S.A.(2009). Antecedents of vertical integration: Transaction cost economics and resource-based explanations. Journal of Purchasing and Supply Management, 15 (2):89-102.

44. Hamel, G., \& Phaladad, C.K.. (1994). Competing for the Future, HBS Press, Boston, MA. USA

45. Hammer, M. (2001). The superefficient company. Harvard Business Review, September: 81-91.

46. Hammer, M. \& Champy, J. (1993). Reengineering the Corporation: A Manifesto for Business Revolution, Harper Collins Publishers, Inc., New York.

47. Harland, C.M. (1996). Supply Chain Management: Relationships, Chains and Networks, British Journal of Management, 7 (special issue): S63-S80.

48. Huws, U. \& Dahlmann, S. (2004). Outsourcing of ICT and Related Services in the EC: A Status Report. Retrieved 6th August, 2012 : http://www.eurofound.europa.eu/emcc/content/source/tn04048s.htm

49. Jabbour, L. (2008). Outsourcing, offshoring and Firm's Performance :Evidence from the French Manufacturing Industry, Centre D‘économie de la Sorbonne(CES), Université Paris 1 Panthéon-Sorbonne and CNRS, France .

50. Jacoby, D. \& Figueiredo, B. (2008). The Art of High Cost Country Sourcing, Supply Chain Management Review, May/June, 2008.

51. Jara, J. \& Escaith, H., (2012). Global Value Chains, International Trade Statistics and Policymaking in a Flattening World, World Economics, 13(4):19-38

52. Javalgi, R.G., Dixit' A., \& Scherer, RF. 2009. Outsourcing to emerging markets: Theoretical perspectives and policy implications, Journal of International Management, 15 (2): 156-168.

53. Jiang, B. \& Qureshi, A. 2006. Research on outsourcing results: current literature and future opportunities. Management decisions, 44(1): 44-55.

54. Johansson, B., \& Löö, H.2008. The Impact of Firm's R\&D Strategy on Profit and Productivity, CESIS Electronic Working Paper Series, Paper No. 156, Centre of Excellence for Science and Innovation Studies (CESIS), The Royal Institute of technology, http://www.cesis.se

55. Jones, Ronald. 2006. Production Fragmentation and Outsourcing. General Concerns", Rochester: University of Rochester, mimeo.

56. Kakumanu, P. \&Portanova, A. 2006. Outsourcing: Its Benefits, Drawbacks and other Related Issues" Journal of American Academy of Business, Cambridge. 9(2):1-7.

57. Koulopoulos, T. 2006.Value Creation Through Smart-Sourcing, InformationWeek, URL: http://www.informationweek.com/news/180207019

58. Kotabe, M., Mol, M.J., Murray, J. \& Parente, R. 2012. Outsourcing and Its implications for market success: negative curvilinearity, firm resources, and competition. Journal of the Academy of Marketing Science, 40:329-346.

59. Kotabe, M., \& Murray, J. 1990. Linking product and process innovations and models of international sourcing in global competition: a case of foreign multinational firms. Journal of International Business Studies, 21(3): 383-408.

60. Krippendorff, K. 2003. Content Analysis: An Introduction to Its Methodology, 2nd ed., Sage, Thousand Oaks, CA.

61. Kusaba, K., Moser,R. \& Rodrigues, A.M. 2011. Low cost country sourcing competence: A conceptual framework and empirical analysis. Journal of Supply Chain Management, 47(4).

62. Leahy, D., \& Montagna, C. 2008. Make or Buy in International Oligopoly and the Role of Competitive Pressure. GEP Research paper, University of Nottingham.

63. Liesch, P.W., Buckley, P.J., Simonin, B.L.,\& Knight, G. 2012.Organizing the Modern Firm in the Worldwide Market for Market Transactions. Management International Review, 52:3-21.

64. Lewin, A. Y., Massini, S., \& Peeters, C. 2009. Why are companies offshoring innovation? The emerging global race for talent. Journal of International Business Studies, 40(6): 901-925. 
65. Stephan, M., \& Silvia, M. (2008). A dynamic perspective on next-generation offshoring: The global sourcing of science and engineering talent. The Academy of Management Perspectives, 22(3), 35-54.

66. Lin, S., Piercy, N., \& Campbell, C.2012. Beyond the make-or-buy dichotomy: outsourcing creativity in the fashion sector. Production Planning \& Control: The Management of Operations. Vol. XXX

67. Lunati, M. 2007. Enhancing the Role of SMEs in Global Value Chains. Global Value Chains SME and Entrepreneurship Division of the OECD Centre for Entrepreneurship, SMEs and Local Development (CFE).

68. Manring, S. \& Moore, S. 2006. Creating and managing a virtual inter-organizational learning network for greener production: a conceptual model and case study. Journal of Cleaner Production; 14:891-9.

69. McCann, P., \& Mudambi, R. 2004. The Location Behavior of the Multinational Enterprise: Some Analytical Issues, Growth and Change, Gatton College of Business and Economics, University of Kentucky, 35(4): 491-524.

70. McKinnon, J. 1988. Reliability and validity in field research: some strategies and tactics. Accounting, Auditing and Accountability, No. 1, 34-54.

71. McNally, R.C. \& Griffin, A. 2004. Firm and Individual Choice Drivers in Make-or-Buy Decisions: A Diminishing Role for Transaction Cost Economics? Journal of Supply Chain Management, 40(1), 4-17.

72. McIvor, R. 2009. How the transaction cost and resource-based theories of the firm inform outsourcing evaluation. Journal of Operations Management, 27: 45-63.

73. McIvor, R., Humphreys, P., Wall, A. \& McKittrick, A. 2009. A Study of Performance Measurement in the Outsourcing Decision, CIMA publishing, UK.

74. Mintzberg, M.1983. Structure in fives: Designing effective organizations, Prentice-Hall (Englewood Cliffs, N.J.).

75. Mintzberg, H.1979. Patterns is strategy formation. Management and Organisation IX (3), 67-86.

76. Moatti,V. 2008. "Low cost sourcing... or high cost supplying ?", Actes de la XVIIème conférence de l'Association Internationale de Management Stratégique, 2008, 28-31 May, Nice, France.

77. Mohiuddin, M., Su, Z., \& Su, A., (2010), "Towards Sustainable Offshore Outsourcing: A case study of Quebec manufacturing Firms Outsourcing to China", The Journal of CENTRUM cathedra". Vol. 3, issue 1. P.84-95. www.centrum.pucp.edu.pe/journal

78. Mohiuddin, M., \& Su, Z.2010. Firm level Performance of offshore outsourcing strategy of manufacturing enterprises: A Research Agenda", Competition Forum, 8(1): 13-27.

79. Mudambi, R. 2008. Location, control and innovation in knowledge-intensive industries. Journal of Economic Geography, Oxford University Press, 8(5): 699-725,

80. Mudambi, R.2007. Offshoring: economic geography and the multinational firm. Journal of International Business Studies, 38: 206-10.

81. OECD.2007.Staying competitive in the global economy: Compendium of studies on global value chains.

82. OECD Factbook 2008: Economic, Environmental and Social Statistics.

83. Pfohl, H.C \& Buse, H.P. 2000. Inter-organizational logistics systems in flexible production networks: an organizational capabilities perspective", International Journal of Physical Distribution \& Logistics Management, 30(5): 388-408.

84. Pyndt, J. \& Torben, P. 2006. Managing Global Offshoring Strategies, Copenhagen: CBS Press.

85. Quinn, H. 1994. Strategic outsourcing, Sloan Management Review, summer: 43-55.

86. Rashid, MM. \& Al-azad, MS. (2013). Relocating Low-to-Medium Tech Manufacturing Activities to Developing Countries: Empirical Analysis of Taiwanese and South Korean Manufacturing Outsourcing to Bangladesh. Journal of "Transnational Corporation Review", 5(2): June-2013.

87. Roberts, J. 2004. The Modern Firm: Organizational Design for Performance and Growth, Oxford University Press.

88. Saldana, J.2011. Fundamentals of Qualitative Research. Oxford University Press.

89. Scully, J.I. \& Fawcett, S.E. 1994.International procurement strategies: challenges and opportunities for small firm, Production \& Inventory Management Journal, 35(2):39-46.

90. Sinha, P., Akoorie, M.E.M, Ding and Wu. 2011. What motivates manufacturing SMEs to outsource offshore in China?: Comparing the perspectives of SME manufacturers and their suppliers, Strategic Outsourcing: An International Journal, 4(1):67-88

91. Slepniov, D. \&Waehrens, B.V.2008.Offshore outsourcing of production: An exploratory study of process and effects in Danish companies. Strategic Outsourcing: An International Journal, 1 (1):64-76. 
92. Stake, R.E. 2006. Multiple Case Study Analysis. New York: Guilford Press.

93. Stake, R.E. 1995. The art of case study research, Thousand Oaks: Sage.

94. St-Pierre, J. 2011. Mondialisation et internationalisation des PME : Le comportement des PME

95. manufacturières québécoises, Institute de Recherche sur les PME, UQTR. Canada.

96. Su, Zhan.2009. Participation de la Chine à la Nouvelle Division Internationale du Travail: Défis et Perspectives, Revue Économique et Sociale, 67(1).

97. Treffler, D.2008. Policy Responses to the New Offshoring: Think Globally, Invest Locally. Ottawa: Industry Canada Working Paper Series, 2008-11-25.

98. Tomiura, E. 2007. Foreign Outsourcing, Exporting and FDI: A productivity Comparison at the Firm Level.Journal of International Economics, 72: 113-127.

99. Torsilieri, J.D. and Lucier,C. 2000. Climbing Up the Value Ladder, strategy and business issue 21.

100. Tsang, E.W.K. 2000. Transaction cost and resource-based explanations of joint ventures: a comparison and synthesis, Organizational Studies, 21 (2000): 215-242

101. UNCTAD (2011): World Investment Report, 2011.

102. WTO. 2011. Made in World Initiative, http://wto.org/english/res_e/statis_e/miwi_e/miwi_e.htm

103. Yin, R.K.1981.The case study as a serious research strategy. Science communication, 3(1): 97-114.

104. Yin, R. K.1994. Case study research: Design and methods ( $2^{\text {nd }}$ ed.). Newbury Park, CA: Sage Publications.

105. Zee, F.A van der \&Brandes, F. 2007. "Manufacturing Futures for Europe: A survey of the literature", TNO the Netherlands, available at:

http://ec.europa.eu/enterprise/enterprise_policy/industry/doc/future manufacturing europe literature final report.pdf 


\section{ANNEX 01: INTERVIEW GUIDE}

\section{Interview Guide on Offshore outsourcing of Canadian manufacturing SMEs}

1. What kind of manufacturing activities your firm is engaged in? Please indicate the unit of your company for which you are responding (e.g., corporate, division, SBU (strategic Business unit), region).

2. How widely used is offshore outsourcing?

3. How deeply has offshore outsourcing penetrated company value chains?

4. What is being offshore outsourced and why?

5. What revenue growth is expected thanks to offshore outsourcing?

6. If you do have offshored to multiple regions/ countries, Is there any regional difference of type of activities off-shored? Offshore outsourcing benefits as well as strategies?

7. Please indicate your current and expected future level (\%) of outsourcing for the following activities. (Research \& Development, Product and service development, Procurement/Supply management, Engineering/detailed design, Manufacturing/ operations).

8. For those activities that you are currently offshoring or will offshore, what are the primary reasons that you chose to outsource?

9. For those activities that you are not outsourcing, and do not plan to outsource, what are the primary reasons you have chosen not to outsource?

10. Where you have chosen to offshore outsourcing of some activities, to what extent have you met your goals on these performance dimensions? If the performance dimension was not a goal, please indicate the reasons for outsourcing?

11. How do you qualify the effect of offshore outsourcing on your company's performance trend over the last three years in terms of Total revenue, Market share, customer satisfaction, Manufacturing efficiency, time to market, innovation and investment on core competency/ies?

12. Do offshoring strategies achieve their stated objectives of improving performance, productivity, market share and quality and overall competitivity of your firm?

13. What range of cost savings have you realized from your outsourcing efforts? Range: (Too early to tell, none, $1-5 \%, 6-10 \%, 11-15 \%, 16-20 \%, 21-25 \% 26-30 \%$, Over $30 \%$ ).

14. For those activities that you have outsourced, please indicate the activity where you have had the overall best results and the overall worst results?

15. How important is the cultural issues when doing offshore outsourcing in a foreign country?

16. Can you please comment on protecting jobs here in Quebec/Canada and overall survival of your firm? 